\title{
A Lifelong Perspective for Growing Music Teacher Identity
}

\author{
Siew Ling Chua ${ }^{1}$. Graham F Welch ${ }^{2}$
}

${ }^{1}$ Singapore Teachers' Academy for the aRts, Singapore

${ }^{2}$ UCL Institute of Education, United Kingdom

Corresponding author:

Siew Ling Chua, Singapore Teachers' Academy for the aRts, 2 Malan Road, Singapore 109433. Email: CHUA_Siew_Ling@moe.gov.sg

\section{Introduction}

"We teach who we are" (Palmer, 1997). Such a maxim has found resonance in the work of many general education scholars who have argued that teacher identity reflects not just the professional aspects of a teacher, but also the personal life experiences and biographies of a human being (Beijaard, Meijer, \& Verloop, 2004; Bukor, 2015; Cardelle-Elawar, Irwin, \& Sanz de Acedo Lizarraga, 2007; Hirsch, 1993; Skerrett, 2008). Identity has been defined as a view of oneself in a social position that is shaped by social interactions (Hargreaves, Miell, \& MacDonald, 2002). By extension, music teacher identity is a view of oneself as a music teacher shaped by one's social interactions.

This article begins with a brief literature review of music teacher identity and of learning and identity. It argues that the notion of transformative learning should be considered when taking a longer-term view of growing music teacher identity across their career lifespan so that teachers achieve self-actualization and a state of flourishing. The article describes the methodology used in a recently completed study and presents the qualitative findings of the seven themes which emerged from the range of transformative learning experiences in the associated case studies. The themes include personal self, activist identity, music, teaching, students, social relations, and ecology of the social world. It discusses how the themes are supported by literature and concludes that there are much larger goals for a life-long perspective of music teacher growth since music teachers bring their whole being into their music teaching.

\section{Literature Review}

\section{Music Teacher Identity}

There is much literature on the construction of music teacher identity at preservice level. Music education scholars have given attention to developing teacher identity so as to prepare preservice teachers for their professional needs as educators (e.g., Ballantyne, 
Kerchner, \& Aróstegui, 2012; Bouij, 2007; Garnett, 2014; Roberts, 2004). Others have advocated strengthening the musician identity (Bernard, 2005; Freer \& Bennett, 2012; Pellegrino, 2011, 2015). There are also scholars who have urged going beyond the binary focus on musician and teacher as constructs of music teacher identity (Dawe, 2007; Dolloff, 2007; Regelski, 2007). More recently, for example, McClellan's (2017) socialcognitive theoretical framework synthesized various theoretical models (Bouij, 1998; Brewer, 2009; D.J. Hargreaves, Purves, Welch, \& Marshall, 2007; McClellan, 2017; Wagoner, 2011). The resultant framework included music teacher self-efficacy and selfconcept, musician-teacher orientation, intersections of music-making and music-teaching roles as music teacher, social identity resulting from interactions and influences in the school of music culture and social environment, and the commitment of time in demonstrating value for music education in a training environment.

For in-service music teachers, where professional development can help to sustain them through their career lifespan, literature has suggested that there are different phases in a teacher's teaching career and that these should be considered in facilitating teacher growth (e.g., Ballantyne, 2006; Conway \& Eros, 2016; Conway, 2008). Others have looked across a spectrum of professional development approaches from skills development to renewal and emancipation (e.g., Sachs, 2011). More recently, Ballantyne and Zhukov (2017) adopted a theory of 'flourishing' from positive psychology to urge for a more encompassing look at varied factors - such as positive emotions, engagement, relationships, meaning and achievements - that influence teacher identity development. There is also literature from general education researchers that has focused on the personal rather than the functional aspects of professional learning (E. Hargreaves \& Preece, 2014).

In this light, this study examined how music teacher identity is shaped and developed from a lifelong perspective. One suggestion would be to work towards a sense of self-actualization. 'Self-actualization' (Maslow, 1962) is an 'episode' in which the individual feels 'more integrated and less split, more open for experience, more idiosyncratic, more perfectly expressive or spontaneous, or fully functioning, more creative, more humorous, more ego-transcending, more independent of his [or their] lower needs' and that he [or they] becomes 'more truly himself [or themselves]' and 'closer to the core of his [or their] Being' (p. 91). It refers to instances where the individual experiences actualizing their potential.

\section{Learning and Identity}

Music teacher identity is connected to different facets of their self. For example, the 'ethical self' determines for the teacher what counts as correct action (Elliott \& Silverman, 2014; Regelski, 2012a, 2012b). 'Self-efficacy' (Bandura, 1997), which is the belief in one's capabilities to act to produce a given attainment, impacts on the effort that teachers make, their resilience, their relationship with students, and their enthusiasm and commitment to teaching (Goddard, Hoy, \& Hoy, 2004; Skaalvik \& Skaalvik, 2014; Tschannen-Moran, Hoy, \& Hoy, 1998; Yost, 2006). 'Self-concept' refers to our evaluations of ourselves (Stets \& Burke, 2003) and our idealised views of ourselves, and has played a part in changing the way that we act or think when there is a difference 
between one's actual and ideal self-concept (Dolloff, 2007; Flores \& Day, 2006; Higgins, 1987; Rodgers \& Scott, 2008). Arising from self-concept, the notion of 'possible-selves' (Erikson, 2007; Markus \& Nurius, 1986) has been found to be empowering, as it can encourage the individual to develop and reach their full-potential concerning the future, based on an understanding of past and present selves. Possible-selves has also been examined in relation to musical identities (Flynn \& Johnston, 2016; Schnare, MacIntyre, $\&$ Doucette, 2012). Another facet of self is an emotional self, where there is increasing recognition of how identity is influenced by emotion (Dolloff, 2007; Flores \& Day, 2006; Rodgers \& Scott, 2008). Music teachers are also negotiating their teaching self, which is an identity to teach (Danielewicz, 2001) that is a complex amalgam of role identity, teacher beliefs and knowledge, and their musical self or musical identity (D.J.

Hargreaves, Miell, \& MacDonald, 2002). And, there is also a sense of a 'we-self' which is the sense of being part of a group, part of being a teaching community or the larger community. Overall, there are different aspects of 'self' interacting and contributing to an individual's learning or not. These 'selves' are not separate, but are customarily part of an integrated whole.

Learning has been closely associated with identity development. It could be observed that learning takes place beyond the conscious rational. For example, musical experiences are embodied (DeChaine, 2002; O’Neill, 2017), experienced physically, emotionally, cognitively and, for some, spiritually. Music learning does not just take place in formal contexts, but also in informal and non-formal learning contexts (Green, 2002; Lum, 2008; Pitts, 2012). Different kinds of experiences - musical encounters, teaching encounters, and other non-music encounters - provide the bases for music teachers' learning. Social learning theories of Vygotsky and Bandura, and social perspectives of learning, have shown how learning is influenced by social context. Music making has also been found as a site to engage in, express, and formulate identity politics (Hess, 2019). Music teachers develop their own unique music teacher identity as a result and, at the same time, are socialized as music teachers, and impacted in their respective music learning ecologies (O’Neill, 2017).

There are also different orientations to learning, such as whether there is a readiness to learn (Knowles, 1973) and desire to change (E.W.Taylor \& Cranton, 2013). The sense of negativity and discontinuity of experiences (Gadamer, 1960/2004), the disruption and struggle experienced, potentially opens up the individual to powerful, transformative learning.

In the professional development of in-service music teachers, which takes a longer-term view of their growth across their career lifespan, therefore, there is a need to give thought to the concept of 'transformative learning', which is defined by Illeris (2014) as 'learning which implies changes in the identity of the learner' (p. 40). Transformative learning, as a theory, was introduced by Mezirow (1997) as a process of 'effecting change in a frame of reference' (p. 5), which is the 'emancipatory process of becoming critically aware of how and why the structure of psycho-cultural assumptions has come to constrain the way we see ourselves and our relationships' (Mezirow, 1981, p. 6, emphasis is original). Over the years, debates on the subject have broadened and transformative learning studies have given attention to affective, spiritual and cultural 
processes (Boyd \& Myers, 1988; Charaniya, 2012; Healy, 2000; Tisdell, 2003), intuition, extrarational knowing, relational knowing, and the unconscious development of thoughts and actions (E.W.Taylor, 1998). Transformative learning can take place gradually over a series of experiences, or abruptly through a sudden powerful experience (Baumgartner, 2001; Mezirow, 1981; E.W.Taylor, 2017). Some of the latest discourse has associated transformative learning with 'Bildung' (Laros, Fuhr, \& Taylor, 2017) which can be described as the cultivation of human capacities and the state of being cultivated or educated (Fuhr, 2017). Hence, transformative learning can be said to be associated with learning as a lifelong endeavour.

Illeris (2014) also suggests that transformative learning could be progressive, regressive, restorative and collective. Progressive transformation is when learning leads to improvement, 'that in some way has to do with the identity, understanding, a way of behaviour, a mode of experience, is changed into something better, more proper, more promising or more rewarding' (p. 93). Regressive transformative learning takes place when there is a sense of withdrawal into a 'safe position' or 'practicable position' (p. 94) because the learner is unable to cope with the new situation, although there is a felt change in their identity. Restorative transformation occurs when the learner turns around from regressive transformative learning, such as when the learner develops an understanding of what went wrong and takes a new progressive transformative course. Collective transformative learning appears when transformative learning takes place collectively where people interact and strengthen their learning together. Such a broadened view of transformative learning theory can facilitate a discussion of the nature and process of music teacher identity, since it focuses on the whole being of the person. It speaks of self-emancipation to achieve personal goals such as self-actualization. Transformative learning is thus the theoretical lens used to guide the current study, with the intention of taking on a lifelong perspective to growing teacher identity to achieve self-actualization.

\section{Methodology}

This article reports on a qualitative study on the lived experiences of 12 music teachers as told through their interviews and shared through other artefacts (e.g., portfolio, videos of their students' work), articles, and sessions with other teachers. The 12 participants were selected from in-service music teachers in Singapore schools and they represent a range of different profiles and experience. ${ }^{1}$ A summary of the participants' profiles is provided in Table 1.

\footnotetext{
${ }^{1}$ Generalist music teachers in Singapore is a term that customarily refers to music teachers who were not originally prepared to teach music or who have had little preparation at pre-service level to teach music. The term is also used to refer to music teachers who are also deployed to teach other subjects and who do not soley specialize in music teaching. Conversely, specialist music teachers were prepared to teach music at pre-service level and are usually deployed to teach more music compared to other subjects they may also teach.
} 
Table 1: Participants

\begin{tabular}{|c|c|c|c|c|c|}
\hline & $\begin{array}{l}\text { Experience } \\
\text { of teaching } \\
\text { the level }\end{array}$ & Experience & $\begin{array}{l}\text { Subject } \\
\text { Proficiency }(\mathrm{SP})^{2} \\
\& \text { Qualifications } \\
\text { in music or music } \\
\text { education }\end{array}$ & Role & $\begin{array}{l}\text { Approximate } \\
\text { Years of } \\
\text { Teaching } \\
\text { (Years of } \\
\text { teaching } \\
\text { music if } \\
\text { different) } \\
\end{array}$ \\
\hline Bess & $\begin{array}{l}\text { Pri and } \\
\text { Sec** }\end{array}$ & $\begin{array}{l}\text { Teaching other } \\
\text { subjects; } \\
\text { Teaching just } \\
\text { music; } \\
\text { Teaching } \\
\text { examination music }\end{array}$ & $\begin{array}{l}\text { Converted from } \\
\text { SP3 to SP1; } \\
\text { Music Ed degree }\end{array}$ & $\begin{array}{l}\text { Senior } \\
\text { Teacher } \\
\text { (Music) }\end{array}$ & $\begin{array}{l}\text { Over } 30 \\
\text { years }\end{array}$ \\
\hline $\mathrm{Pal}$ & Pri & $\begin{array}{l}\text { Teaching other } \\
\text { subjects; } \\
\text { Teaching just } \\
\text { music }\end{array}$ & $\begin{array}{l}\text { Converted from } \\
\text { SP3 to SP1; Adv } \\
\text { Dip; Pursuing } \\
\text { Masters } \\
\end{array}$ & $\begin{array}{l}\text { Senior } \\
\text { Teacher } \\
\text { (Music) }\end{array}$ & 9 years \\
\hline Jam & $\mathrm{Sec}$ & $\begin{array}{l}\text { Teaching just } \\
\text { music; } \\
\text { Teaching } \\
\text { examination music }\end{array}$ & $\begin{array}{l}\text { SP1; Pursuing a } \\
\text { part-time music } \\
\text { ed degree }\end{array}$ & $\begin{array}{l}\text { Music } \\
\text { coordinator }\end{array}$ & 5 years \\
\hline Ren & $\mathrm{Sec}$ & $\begin{array}{l}\text { Teaching just } \\
\text { music; } \\
\text { Teaching } \\
\text { examination music }\end{array}$ & SP1; Masters & $\begin{array}{l}\text { Head of } \\
\text { Department }\end{array}$ & 19 years \\
\hline Thomas & $\mathrm{Sec}$ & $\begin{array}{l}\text { Teaching just } \\
\text { music }\end{array}$ & SP1; Masters & Music teacher & $\begin{array}{l}\text { Less than } 1 \\
\text { year }\end{array}$ \\
\hline Zak & $\mathrm{Sec}$ & $\begin{array}{l}\text { Teaching other } \\
\text { subjects }\end{array}$ & SP2 & Music teacher & 10 years \\
\hline Wee* & Pri & $\begin{array}{l}\text { Teaching other } \\
\text { subjects; } \\
\text { Teaching just } \\
\text { music }\end{array}$ & $\begin{array}{l}\text { Converted from } \\
\text { SP3 to SP1; Adv } \\
\text { Dip }\end{array}$ & Subject Head & 18 years \\
\hline Dylan & $\mathrm{Sec}$ & $\begin{array}{l}\text { Teaching other } \\
\text { subjects }\end{array}$ & $\begin{array}{l}\text { SP1; Bachelor } \\
\text { Music }\end{array}$ & Music teacher & 3 years \\
\hline Shing & Pri & $\begin{array}{l}\text { Teaching other } \\
\text { subjects }\end{array}$ & $\begin{array}{l}\text { SP3 } \\
\text { (just converted } \\
\text { from full-load } \\
\text { music teacher to } \\
\text { generalist music } \\
\text { teacher) }\end{array}$ & $\begin{array}{l}\text { Music } \\
\text { coordinator }\end{array}$ & 7 years \\
\hline Joan & $\mathrm{Sec}$ & $\begin{array}{l}\text { Teaching just } \\
\text { music }\end{array}$ & $\begin{array}{l}\text { SP1; Music } \\
\text { degree }\end{array}$ & $\begin{array}{l}\text { Music } \\
\text { coordinator }\end{array}$ & 1.5 years \\
\hline
\end{tabular}

\footnotetext{
${ }^{2}$ Subject proficiency is used by the Ministry of Education (MOE) for deployment purposes. In most cases, it corresponds to the same order as the teachers' CS or 'Curriculum Studies'. CS refers to the subject that teachers learned to teach in their pre-service education. Teachers who are considered qualified to teach music by the MOE are categorized as SP1 and SP2 respectively. The SP (subject proficiency) guides the deployment of the teacher since schools are encouraged to deploy SP1 teachers to teach more music periods in their teaching load. A teacher's SP might be adjusted in their career due to courses that they have attended.
} 


\begin{tabular}{|c|c|c|c|c|c|}
\hline & $\begin{array}{l}\text { Experience } \\
\text { of teaching } \\
\text { the level }\end{array}$ & Experience & $\begin{array}{l}\text { Subject } \\
\text { Proficiency }(\mathrm{SP})^{2} \\
\& \text { Qualifications } \\
\text { in music or music } \\
\text { education }\end{array}$ & Role & $\begin{array}{l}\text { Approximate } \\
\text { Years of } \\
\text { Teaching } \\
\text { (Years of } \\
\text { teaching } \\
\text { music if } \\
\text { different) }\end{array}$ \\
\hline Cassie* & Pri & $\begin{array}{l}\text { Teaching other } \\
\text { subjects; } \\
\text { Teaching just } \\
\text { music }\end{array}$ & $\begin{array}{l}\text { Converted from } \\
\text { SP3 to SP1; Adv } \\
\text { Dip }\end{array}$ & $\begin{array}{l}\text { Senior } \\
\text { Teacher } \\
\text { (Music) }\end{array}$ & 16 years \\
\hline Chang & $\mathrm{Sec}$ & $\begin{array}{l}\text { Teaching other } \\
\text { subjects }\end{array}$ & Not Applicable & $\begin{array}{l}\text { Head of } \\
\text { Department }\end{array}$ & $\begin{array}{l}8 \text { years (but } \\
\text { only taught } 2 \\
\text { years of } \\
\text { music) }\end{array}$ \\
\hline
\end{tabular}

"Wee and Cassie belong to the same school. The rest of the participants are from different schools in Singapore. ${ }^{*}$ Pri and Sec represents Primary (students of age 7-12) and Secondary (students of age 13-16) levels respectively.

Using a River of Experience approach (Denicolo \& Pope, 1990; Pope \& Denicolo, 1993), participants were invited to reflect on the turning points in their lives which they perceived to have been most impactful on their music teacher identities. Turning points, which are significant episodes in one's life, have been included as part of studies relating to personal identity (e.g., Cappeliez, Beaupré, \& Robitaille, 2008; McLean \& Pratt, 2006). Reflecting upon a turning point in one's life also provides an opportunity for a negotiation of one's identity. Participants were asked to draw their personal River of Experience which reflected the turning points in their life that had impacted most on the way that they thought about teaching-learning. After they drew their River of Experience, participants were asked about their maps. Questions included 'Is there anything from that experience that you think was really useful for you now?', and 'What's the greatest impact that this/they have had on you as a music teacher?'

The interviews took place over a year, with between one to two interviews for each participant. These were audio-recorded and transcribed with oTranscribe (n.d.) (https://otranscribe.com/), with the total interview duration for each participant ranging from 70 to 150 minutes. The transcripts of the interviews were then analysed. First, narrative analysis (Riessman, 1993) was applied to each case so that the identity of teachers and the chronological features of the accounts were laid out. Along with the narrative analysis, techniques of interpretative phenomenological analysis (IPA) were also adapted to investigate how participates made sense of their reported experiences (Smith, Flowers, \& Larkin, 2009). As IPA provided insights into psychological and social processes, it supported the narrative research process in this study. IPA has been used previously in combination with a River of Experience (Taylor, 2011, 2015) because it 'enables participants to act as co-researchers determining the course of their interviews democratically' (p.440). Arguably, the process provided a more nuanced understanding of the participants' experiences, specifically in how their signalled turning points were seen as transformative to their professional identity and sense of agency as a music teacher.

Next, the narratives for each participant were then coded both inductively and deductively. The initial themes investigated related to personal identity, music identity 
and teacher identity. The narratives were coded inductively using causation coding (Saldana, 2013, p. 163-75) to identify the relationship between participants' areas of development and the perceived impact on their identity. The thematic analysis was intended to highlight, transformative areas of development in the professional identity and agency of the participants.

Narratives were then checked with the participants, which was where further meetings or email discussions took place. Their additional comments and input were considered as their write-ups were worked on again. The final accounts of participants were the result of iterative processes of revisiting and co-constructing the narratives, based on the original sets of interviews and subsequent reflections. Finally, a cross case analysis was conducted using NVivo 11 (QSR International Pty Ltd, 2015). The process yielded seven themes.

The study conformed to ethical guidelines for research. Voluntary informed consent was obtained from all participants before data were collected. Clearance was sought from the Ministry of Education (MOE), Singapore, since data were collected from MOE teachers, as well as from the University. Participants were briefed individually on the purpose of the research, the commitment involved, how the data would be used, and how findings might be reported. They were also informed that they could withdraw from the research at any point for any or no reason until the finalisation of the draft report. Where there were potential concerns about possible threats to anonymity, this was highlighted for the participants. For example, since Cassie and Wee belonged to the same school, both participants were informed of their mutual participation and their consent sought before their write-ups were made available to each other.

\section{Findings}

The case studies revealed a range of transformative learning experiences and seven main themes emerged. This section presents examples of these transformative learning experiences through narratives to illustrate each of the themes. Pseudonyms have been used to remove forms of identifiers (e.g., school name) in order to ensure anonymity.

\section{Personal Self}

The narratives showed that different facets of self (such as ethical self, self-efficacy, selfconcept) interact to energize or de-energize teacher identity. For example, transformative learning could occur when certain experiences disrupted beliefs and self-concept, or when pursuing a possible self. Such learning could also be stimulated by other personal biographical encounters.

A participant, Ren, recounted that one of the turning points in his life which contributed to his music teacher identity was his meeting with an 'authoritarian' voice teacher who threatened that Ren 'learn to submit' to him and his teachings, or Ren would have to leave in the middle of his graduate studies. Ren felt that his autonomy was violated when his teacher forced him to 'submit' to him. However, as he did not have a choice, he withheld his own judgements and gave attention to the new practice and, in so doing, grew to appreciate his teacher's objectives. He reported that he then grew to 
appreciate the lessons from his voice teacher which taught him to develop a 'real and truthful' voice so that it reflected his 'true self.' Arguably, the initial confrontation jolted him out of his egotistical self which led him to understand the underpinning philosophy of his voice teacher. He reported experiencing a transformation in his disposition to learn. The experience, along with others, helped shape his philosophy for teaching, which is to 'let the students be themselves'. However, unlike his authoritarian teacher, he would 'try to find a point where students find it most safe to express themselves', and this was evident in his observed music lessons.

The above is an example of learning that was not actively sought, but experienced in a passive, receptive sense. It echoes an assumption of learning mentioned earlier, that having a sense of negativity (Gadamer, 1960/2004) potentially opens one up to powerful, transformative learning. This negativity refers to the gaps in our experience that leads us to question and struggle within ourselves. The negativity presented itself when Ren experienced a certain threat to his own self-efficacy, self-concept and initial personal belief about singing. The example also reminds us of the receptive stance in selfactualization (Maslow, 1962), where the 'Being' cognition is more passive and receptive than active.

\section{Activist Identity}

Several of the participants reported how, having multiple role-identities or a change of identity, could trigger transformative learning and support a sense of agency as a music teacher. For example, Shing, who used to be teaching a full-complement of music lessons, took on the role of a form teacher ${ }^{3}$ and taught other subjects. The role of a form teacher provided her with a greater sense of agency in enabling a class music performance in her school context because she felt more empowered as a teacher who, in a sense, owned her class. Paradoxically, she reportedly saw, for the first time, that she could arrange for her class to create a music performance for a school event. She also began to see interdisciplinary possibilities, such as integrating physical education and music within her curriculum.

In another case, Chang, a generalist music teacher who had taken on a leadership role in her school, identified the running of a public performance in her school as a turning point for her. The event, seen by her as 'one of the biggest platforms to advocate for music in the school' and that 'every student performs, good or no good', consisted of three evenings of concerts by lower Secondary music students (age 13-14). The event facilitated an activist message that she strived to bring across, that 'every student can do something with music, and music benefit[s] every student'. She reported that the experience enabled her to see how music performance could be a community event which became part of the school culture - a time when the upper Secondary students returned to support the lower Secondary students in their performance. The experience also enabled her to consider why and how music performing experiences can impact on student development. When she saw individual student successes, it evoked something deeper in

\footnotetext{
${ }^{3}$ The form teacher takes responsibility of a class and generally gets to know the students more as there are opportunities for other interactions with the class of students.
} 
her as an educator, emotionally connecting her to a sense of purpose which went beyond the normal call of duty.

... everybody can try to tell me that it's too much work and all that; I will still try to make sure I can do everything in my power to give this.

From the above examples, the activist identity was seen to be sparked due to teachers' rooted beliefs in achieving the mission and vocation that they had in themselves as teachers. There was a sense of ownership of the change which resulted from their initiatives, and their close work with the initiative resulted in transformative learning experiences which, in turn, affirmed their music teacher identity through their positive contributions to the school. This sense of transformation might not be so much of a shift in frames of reference; rather, there is a reported expansion of a sense of autonomy and competence, a sense of being in the position to make a difference as a music teacher, a sense of a new self-concept, and a sense of self-actualization, knowing that they were closer to the core of their being ( $c f$ Maslow, 1962).

\section{Music}

Breadth of music exposure and/or depth of the impact of performing experiences also contributed to the participants' sense of self-efficacy as music teachers. For example, for Chang, although she was a generalist music teacher who had never undergone pre-service music teacher education, her craft knowledge as a performer enabled her to help her students grow as performers. For another participant, Pal, his own private dabbling in electronic music reportedly allowed him to bring digital music into his music lessons, which he felt helped him achieve a more inclusive music class.

Performing experiences were cited by 9 out of 12 participants as having immense impact to the participants' identities. Pal, being moved by his own early performing experiences, had encouraged students' performances and made them as inclusive as possible. He remembered the opportunity given to him when he was 6 years old at a graduation concert in a junior music course where he was made to play the bass drum and crash the cymbals at the end of the song, even though he felt he 'wasn't like the most outstanding student in the class'. However, the experience was 'really impactful'. As a teacher, he felt he could do the same for his students.

When I also get the kids to play the percussion, or do a class performance, when I see some of kids who really have problems, struggling to blend in, I give them a part like that. I realised that is important, you know, through my own experience... So, that's one of my beliefs, [to] try to include everyone.

In addition to what Pal shared in the interview, he also proudly shared with the first author (S.L.C) some recordings of his students' performances. His pride of his students' performances showed how his own musical experiences had impacted on the music teacher identity that he exuded. 
The case studies provided nuanced accounts of how the breadth of musical exposure and depth of performing experiences gave music teachers a sense of selfefficacy to engage their students, and to inspire music beyond their classrooms, and developing an inclusive music culture in school. Engagement with music, the sense of presence of music in their lives, the exposure, and the depth of music experience, collectively developed and sustained a positive music teacher identity, one that-in turn - impacts on their students' musical identities, which then provides teachers with a sense of fulfilment.

\section{Teaching}

There were accounts from participants who seemed to connect the experiences of music teaching with artistic experiences. For example, 3 of the 12 participants cited examples of applied pedagogy courses, namely Kodaly and Orff, as 'turning points'. These provided them with models of how music teaching could be fluent, artful and engaging. Dylan commented that he was impressed by the 'constant state of flow' and found the delivery itself 'very beautiful' and 'an art to see students learning, but they don't know that they are learning; they are just having fun'. It left 'a big impression' in his mind and was 'a point of inspiration'. The narratives suggest that music teaching was seen as an art form of its own. It was impactful to experience or even to watch a model of applied pedagogy in action.

Some of the participants were particularly excited when they articulated their scaffolding approaches as they adapted known methods or approaches. Jam saw teaching as an art of communication which had inspired her to become a teacher in the first place. Her narrative of her growth was very much centred on pedagogical development and how she could teach so that her students understood.

...that was exactly why I was hooked on the job. Because you get the sense of fulfilment if you come up with such innovative ideas and if you teach in a certain way that more people understand what you are trying to say. It's like you will find a different way of communicating with someone.

In various narratives, teachers reinterpreted their past music learning experiences as they tried to evaluate whether this teaching had led to outcomes that were deemed 'good' for students. Previous negative experiences as a student had taught the teachers about what not to do. For example, Thomas had a negative experience with self-directed learning as a student because when he had to research a topic with his peers, he felt that the research done would not prepare them as well for examinations compared to if his teachers provided the lecture and notes. The experience left Thomas questioning the effectiveness of 'self-directed learning' in the light of pragmatic goals of passing examinations. Thus, judgements of what constitute the 'right results' for students are subjective interpretations of experiences.

Collaborative interrogation of teaching, deeper critical thinking about music teaching and on the iterations of music teaching practices, effected collective transformative learning. For example, Wee felt that the envisioning in which she 
participated with her colleagues was a powerful one, one that stimulated re-thinking and re-designing of her school's music curriculum. Similarly, Cassie recalled the experience where she envisioned the principles for student-centred music learning with colleagues as a powerful moment when she realised the kinds of learning music lessons could provide for students. The collaborative visioning was felt to be useful in contributing to a shared understanding and synergy in achieving a vision of good teaching, and hence a collective transformative learning experience.

In summary, music teaching could be experienced as an artistic experience, an art of communication, and evaluated as a form of praxis, in the Aristotelian sense, that involved rational and ethical judgements (Regelski, 1998). The narratives highlighted an inherently emotional and intellectual need in music teachers to interrogate, analyse and reflect on their music teaching. However, teachers could develop negative views of teaching pedagogy when these are left unexamined with others. Hence, teaching experiences themselves might become an inhibitor to teacher growth when they are experienced negatively. The ways that teaching encounters could transform, whether through the subconscious, rational analysis, emotional connections, or artistic experiences, remind us of the need to acknowledge and value a whole range of music teaching experiences in this web of professional learning.

\section{Students}

The impact of students on teachers' learning presented as another significant theme in the narratives of teachers. Teachers' confidence and the achievement of their teacher identity were reported to hinge very much on whether they could engage and motivate students. Students' responses to their teacher's pedagogy can change or reinforce teaching beliefs and sense of self-efficacy. For example, Pal's bad experiences with students at the start of his teaching career was described by him as 'one of the most poignant moments' in his teaching career which he narrated in a sad tone. He felt he had 'totally $100 \%$ lost it' as he was not able to manage a class. With hindsight, he felt that the incident was a 'big learning point'. He only regained confidence when he had positive interactions with students and from whom he felt positivity and respect, and who showed that they could do good work in music. As he realized that he was 'making a difference as a music teacher' when his students were doing well. He experienced a restorative transformative experience.

For Joan, who struggled as a beginning teacher, providing a performing platform for students was impactful emotionally on her identity as a music teacher. She realized that she could value-add as a 'music person', seeing music beyond the subject, and seeing music as a culture that she could grow in her school. When she discovered that her students found the music performance memorable, she perceived a related change in her own identity.

I think the shift for me this year...would be the shift from seeing myself as a teacher teaching these subjects during $x$ number of periods in school into the music person in school... 
Witnessing her students experiencing what she felt personally was most valuable, therefore, was a transformation for Joan. She felt emancipated from the less positive stance of comparing the treatment of music with other subjects and she could begin to pay attention to the broader goals of music education and her role as a music educator. Hence, there was a sense of transformation, a sense of finding her place where she could make a difference in others, and a sense of growth in Joan's music teacher identity.

Students' responses to a teacher's pedagogy can reinforce or change their teaching beliefs, which could be positive or negative. The empirical experience with students' learning can have a strong influence on teacher belief.

\section{Social Relations}

From the case studies, role models (Merton \& Merton, 1968) could be found in mentors, expert others, and peers. Role-models were perceived to resonate with personal beliefs and were identified by the teachers because of values that they appreciate. From this perspective, a teacher's biography plays a part in their identification of a role-model, which helps them construct a possible self.

Besides role-models, friendships and a sense of belonging to a community also contribute to teacher identity development and growth. A strong we-self, such as one that is fostered through collective envisioning and deep conversations about teacher beliefs and practices, can create positive energies for collective transformative learning. The impact of feeling a sense of belonging to a community provides transformative learning opportunities for the teacher. This is evidenced in Joan's narrative. Joan's initial experience of teaching general music was daunting, as she felt it was her 'first experience' and 'being the only teacher there', and having to work with '40 students'. Her identity as a music teacher grew when she felt a sense of being in a community, having other music colleagues with whom she could relate, even though they were from different schools. The other case study participants also revealed several instances where their sense of being in a community supported their music teacher identity. Wee, for example, felt the impact of collective envisioning on the purpose of teaching, which connected with her deeper beliefs as an educator. She has been driven by that vision, which has sustained her across her career.

Individually, we may have our own belief systems... But that team brings us to come together to envision what we want together collectively... Knowing that there is a group of people working together towards the same goal itself, you will put in even more effort. Yes, towards what you really believe music [education] should do.

\section{Ecology of the Social World}

The narratives revealed examples of influences and impediments from a music teacher's social world that could act for or against the growth of music teacher identity. These included power dynamics in the social world, such as access to resources, the privileging of certification and qualifications, social hierarchies, and the generally pragmatic stance taken in our day-to-day interactions. School cultures and larger policies also were seen to 
promote or hinder music teacher identity. These were reminders that achievements related to music teacher identity and agency are also dependent on social conditions and structures. There is a myriad of factors at play in teachers' social contexts and biography that could impact on their learning and identity. Although formal interventions such as graduate courses and milestone professional development programmes were cited by all participants for their impact, most participants (9 out of 12) pointed to informal and nonformal learning experiences rather than formal courses as having a larger impact on their musical identity and music teacher identity. The implication, therefore, is a need for a consideration of teachers' contexts, and to harness a combination of informal, non-formal and formal interventions. Social networks and participatory cultures, for example, are likely to be some of the ways forward for transformative learning of teachers.

\section{Discussion}

The data analyses included a total of 239 codes which were shaped into seven themes from the interviews with the 12 participants that could impact, positively and negatively, on a teacher's growth. It was found that social relations $(20.5 \%)$ constituted the largest occurrence in teachers' transformative journeys. This was closely followed by music (19.2\%), teaching (15.9\%) and an activist identity (15.9\%). The themes of students $(12.1 \%)$, the ecology of the social world $(10.0 \%)$ and the personal self $(6.3 \%)$ had a somewhat lower occurrence of mention amongst the 12 participants as influencers or inhibitors of their transformative learning. Social relations, having the largest prevalence within the themes, points to the nature of humans as social beings and the critical role that relationships play in our learning experiences, which may lend transformative effects to our identity as music teachers. In contrast, personal identity appeared to have the least occurrences in teachers' transformative journeys.

For each of these themes, it could be seen that they are also supported in literature. For the theme 'personal self', general education scholars such as E. Hargreaves and Preece (2014) have called for the need to value the personal in teachers' professional learning. Scholars have also promoted an activist teacher profession (Sachs, 2003) which can draw on learner's 'readiness to learn' (Knowles, 1973) and their 'desire to change' (E.W. Taylor \& Cranton, 2013). Theoretical perspectives such as affect control theory (Heise, 1987) and stress research (Kiecolt, 1994) support the notion that an activist identity is triggered during a change of status quo. As for the impact of music, numerous scholars have written about music participation being integral to identity (DeNora, 2000; Pitts, 2005), how performing experiences confirm identity and self-esteem (Lamont, 2011), how music making is a site to formulate identity politics (Hess, 2019), how music experiences catalysed affective energies (DeChaine, 2002; Olsen, 2008; Qi \& Veblen, 2016), and the connections between the performer and teacher identities (Pellegrino, 2009). The theory of self-efficacy development through mastery experiences (Bandura, 1997) for example, would explain the act of teaching which develops the efficacy for teaching. There are also suggestions of how the teacher is also an artist, as teaching is 'a peculiar form of self-expression in which the artist, the subject, and the medium are one' (Kagan, 1992, p. 164). Studies have also shown the importance of a positive teacherstudent relationship and student well-being on teachers (Bullough \& Pinnegar, 2009; Klassen et al., 2012; Spilt et al., 2011). 
Concerning social relations, many general education scholars have written about the development of identities, such as in communities of practice (Wenger, 2009), and the influence of power (Kemper, 1991) and reference groups (Merton \& Merton, 1968). The discourse on micropolitics in music education (Conway \& Hibbard, 2018; Conway, Hibbard, \& Rawlings, 2015), an ecological approach to agency (Priestley, Biesta, \& Robinson, 2015) and ecological model of partnerships (Flynn \& Johnston, 2016) are built on notions of how human development is influenced by interactions with environmental contexts (Bronfenbrenner, 1993). Learning to teach is a process of socialization and enculturation (Feiman-Nemser, 2003; Feiman-Nemser \& Floden, 1984). Hence, there is an ecological impact of the music teacher's social world on the continued growth of their identity. A visual summary of the themes is given in Fig 1.

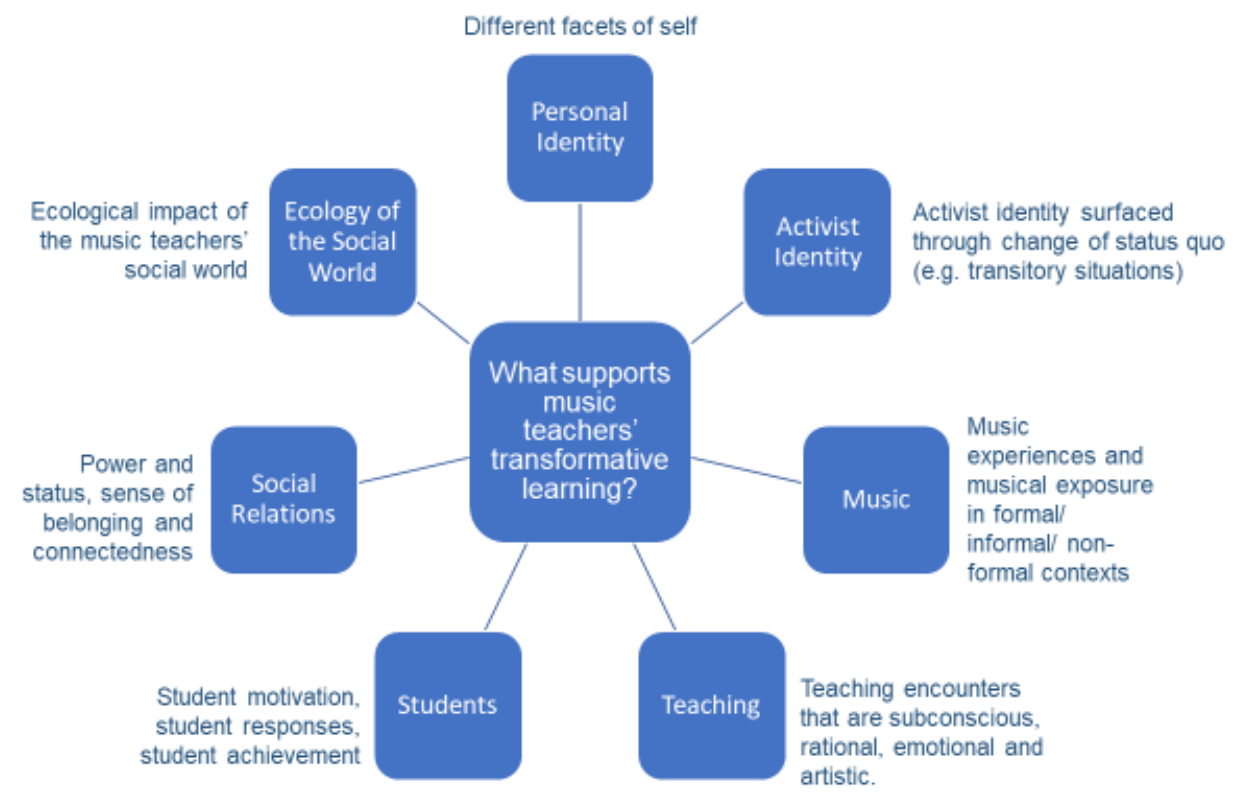

Fig 1: Themes that Support Transformative Learning

Collectively, these themes can bring a new understanding of how we might conceive music teacher identity growth, as well as aspects which might hinder such development. While the themes seem to suggest independent concepts, it could be observed that, in many cases, the transformative learning experiences were supported by multiple themes. For example, in Jam's narrative, her personal self interacted with her activist identity, which also interacted with the influence of her students. Together, these shaped her transformative learning as a music teacher, and hence her professional identity as a music teacher. The relationships between the themes and how they interact for transformative growth might be a subject for future study.

Along with the themes that have been found to contribute to the growth of music teacher identity and agency, the narratives have also pointed to both informal and formal experiences as turning points in teachers' identity development. For example, besides the encounters described in the findings, teacher preparation and professional development 
programmes were also frequently cited by participants as forming part of these transformative learning experiences.

\section{Conclusion}

These themes derive from snapshots taken at the point of the interviews and confirmed in subsequent reviews. We recognize that identities are shifting. We also recognize that the themes could also change with a different profile of participants. There could be other themes that might surface, not only with different participants, but also with different researchers' lenses and experiences. However, although the themes found in this study are particular to the context of the study, they may also appear in other music teachers' transformative journeys. Future work could investigate the other facets of self (e.g., performer self, technological self, cultural self) that might characterize music teachers in other roles, contexts and societies, given that different environments would shape the authentic selves of music teachers differently. Research could also give attention to the affective and spiritual domains (head, heart and soul) in teachers' development. For example, evaluative research of professional development programmes might not just be limited to measures of cognitive outcomes, but also include affective outcomes amongst others.

Whereas much literature has dedicated discussion to the identity development of student teachers becoming new teachers, this study has focused on the growth of identity of the in-service music teacher. This research has outlined particular thematic ideas that can operate to create a progressive, regressive, restorative and collective transformation in music teacher identity. Taking cognisance of these larger influences on identity could help design programmes to strengthen the development of a music teacher in more holistic ways. It would seem that music teachers bring their whole being into their music teaching. Seen in this light, it seems pertinent for music teachers to nurture (and be nurtured in) their whole identity, so that they can continue successfully to grow and support and enrich their students.

There are much larger goals in professional development of in-service music teachers that takes on a life-long perspective of music teacher growth. This article mostly argues that there are at least seven areas that impact on a music teacher identity. Hence, in providing professional development, besides asking what we can do in professional development programmes, we should also ask what conditions would support or inhibit the positive transformative learning of music teachers. We could also ask how we could promote music teacher identities in such ways that music teachers can feel closer to the core of their being, feel the joy and fulfilment of living as a music teacher, and feel a sense of living in their vocation. It should also be pointed out that since identity is open to influence, and environmental contexts continue to change, professional development work is therefore an enduring one. 


\section{Acknowledgement}

The authors wish to thank Rebecca Chew (Academy Principal, until December 2018), Clifford Chua (Academy Principal, from December 2018), and colleagues at the Singapore Teachers' Academy for the aRts for their support in this research.

\section{Funding}

The author(s) received no financial support for the research, authorship, and/or publication of this article.

\section{References}

Ballantyne, J. (2006). Reconceptualising Preservice Teacher Education Courses for Music Teachers: The Importance of Pedagogical Content Knowledge and Skills and Professional Knowledge and Skills. Research Studies in Music Education, 26(1), 37-50. doi:10.1177/1321103X060260010101

Ballantyne, J., Kerchner, J. L., \& Aróstegui, J. L. (2012). Developing music teacher identities: An international multi-site study. International Journal of Music Education, 30(3), 211-226. doi:10.1177/0255761411433720

Ballantyne, J., \& Zhukov, K. (2017). A good news story: Early-career music teachers’ accounts of their "flourishing" professional identities. Teaching and Teacher Education, 68, 241-251. doi:10.1016/j.tate.2017.08.009

Bandura, A. (1997). Self-efficacy: The exercise of control. New York, NY, US: W H Freeman/Times Books/ Henry Holt \& Co.

Baumgartner, L. M. (2001). An Update on Transformational Learning. New Directions for Adult and Continuing Education, 2001(89), 15-24. doi:10.1002/ace.4

Beijaard, D., Meijer, P. C., \& Verloop, N. (2004). Reconsidering research on teachers' professional identity. Teaching and Teacher Education, 20(2), 107-128. doi:10.1016/j.tate.2003.07.001 
Bernard, R. (2005). Making Music, Making Selves: A Call for Reframing Music Teacher Education. Action, Criticism, and Theory for Music Education, 4(2), 1-36.

Bouij, C. (1998). Swedish Music Teachers in Training and Professional Life.

International Journal of Music Education, 32(1), 24-32.

doi:10.1177/025576149803200103

Bouij, C. (2007). A comment to Rhoda Bernard: Reframing or oversimplification?

Action, Criticism, and Theory for Music Education, 6(2), 1-18.

Boyd, R. D., \& Myers, J. G. (1988). Transformative education. International Journal of Lifelong Education, 7(4), 261-284. doi:10.1080/0260137880070403

Brewer, W. D. (2009). Conceptions of effective teaching and role-identity development among preservice music educators. (Doctoral diss.). Arizona State University, Tempe.

Bronfenbrenner, U. (1993). Ecological models of human development. In M. Gauvain \& M. Cole (Eds.), Readings on the development of children (2nd ed., Vol. 3, pp. 3743). New York, NY: W.H. Freeman.

Brookfield, S. (2010). Learning Democratic Reason: The Adult Education Project of Jurgen Habermas. In M. Murphy \& T. Fleming (Eds.), Habermas, Critical Theory and Education (pp. 125-136). New York, NY: Routledge.

Bukor, E. (2015). Exploring teacher identity from a holistic perspective: reconstructing and reconnecting personal and professional selves. Teachers and Teaching, 21(3), 305-327. doi:10.1080/13540602.2014.953818 
Bullough, R. V., \& Pinnegar, S. (2009). The happiness of teaching (as eudaimonia): disciplinary knowledge and the threat of performativity. Teachers and Teaching, 15(2), 241-256. doi:10.1080/13540600902875324

Cappeliez, P., Beaupré, M., \& Robitaille, A. (2008). Characteristics and Impact of Life Turning Points for Older Adults. Ageing International, 32(1), 54. doi:10.1007/s12126-008-9005-4

Cardelle-Elawar, M., Irwin, L., \& Sanz de Acedo Lizarraga, M. L. (2007). A cross cultural analysis of motivational factors that influence teacher identity. Journal of Research in Educational Psychology, 5, 565-592.

Charaniya, N. K. (2012). Cultural-spiritual perspective of transformative learning. In E. W. Taylor \& P. Cranton (Eds.), The handbook of transformative learning: Theory, research, and practice (pp. 231-244). San Francisco, CA: Jossey-Bass.

Conway, C. M. (2008). Experienced Music Teacher Perceptions of Professional Development throughout Their Careers. Bulletin of the Council for Research in Music Education, (176), 7-18.

Conway, C., \& Eros, J. (2016). Descriptions of the second stage of music teachers' careers. Research Studies in Music Education, 38(2), 221-233. doi:10.1177/1321103X16672607

Conway, C., \& Hibbard, S. (2018). Music teachers' lives and the micropolitical landscape of schools. Research Studies in Music Education, 40(1), 89-101. doi:10.1177/1321103X18765461 
Conway, C., Hibbard, S., \& Rawlings, J. R. (2015). The Potential Use of Micropolitics in Examining Personal and Professional Experiences of Music Teachers. Journal of Music Teacher Education, 25(1), 23-36. doi:10.1177/1057083714539768

Danielewicz, J. (2001). Teaching Selves: Identity, Pedagogy, and Teacher Education. Albany: State University of New York Press.

Dawe, N. (2007). Identity and borderland discourse: Bridging the personal and the professional in music teacher identity research. The Canadian Music Educator, $49(2), 39-42$.

DeChaine, D. R. (2002). Affect and embodied understanding in musical experience. Text and Performance Quarterly, 22(2), 79-98. doi:10.1080/10462930216609

Denicolo, P., \& Pope, M. (1990). Adults learning - teachers thinking. In C. Day, M. Pope, \& P. Denicolo, Insights into teachers' thinking and practice (pp. 159-169). London, England: Falmer.

DeNora, T. (2000). Music in Everyday Life by Tia DeNora. Cambridge, UK: Cambridge University Press. doi:10.1017/CBO9780511489433

Dolloff, L.-A. (2007). 'All the Things We Are' : Balancing our Multiple Identities in Music Teaching. Action, Criticism, and Theory for Music Education, 6(2), 1-21.

Elliott, D. J., \& Silverman, M. (2014). Music, personhood, and eudaimonia : implications for educative and ethical music education. The Journal for Transdisciplinary Research in Southern Africa, 10(2), 57-72.

Erikson, M. G. (2007). The meaning of the future: Toward a more specific definition of possible selves. Review of General Psychology, 11(4), 348-358.

doi:10.1037/1089-2680.11.4.348 
Feiman-Nemser, S. (2003). What New Teachers Need to Learn - Educational Leadership. Educational Leadership, 60(8), 25-29.

Feiman-Nemser, S., \& Floden, R. E. (1984). The cultures of teaching. Retrieved from Michigan State University website: http://files.eric.ed.gov/fulltext/ED251423.pdf

Flores, M. A., \& Day, C. (2006). Contexts which shape and reshape new teachers' identities: A multi-perspective study. Teaching and Teacher Education, 22(2), 219-232. doi:10.1016/j.tate.2005.09.002

Flynn, P., \& Johnston, T. (2016). Possible selves in music: Summary of a research partnership. National Concert Hall, Dublin: Music Generation.

Freer, P. K., \& Bennett, D. (2012). Developing musical and educational identities in university music students. Music Education Research, 14(3), 265-284. doi:10.1080/14613808.2012.712507

Fuhr, T. (2017). Bildung: An Introduction. In A. Laros, T. Fuhr, \& E. W. Taylor (Eds.), Transformative learning meets Bildung. [Chapter 1] (pp. 3-16). Retrieved from https://www.sensepublishers.com/media/3021-transformative-learning-meetsbildung.pdf

Gadamer, H.-G. (2004). Truth and Method (J. Weinsheimer \& D. G. Marshall, Trans.). New York: Bloomsbury Publishing.(Original work published 1960)

Garnett, J. (2014). Musician and teacher: employability and identity. Music Education Research, 16(2), 127-143. doi:10.1080/14613808.2013.847073

Goddard, R. D., Hoy, W. K., \& Hoy, A. W. (2004). Collective Efficacy Beliefs:Theoretical Developments, Empirical Evidence, and Future Directions. Educational Researcher, 33(3), 3-13. doi:10.3102/0013189X033003003 
Green, L. (2002). How Popular Musicians Learn: A Way Ahead for Music Education. Ashgate Publishing, Ltd.

Hargreaves, D. J., Miell, D., \& MacDonald, R. A. (2002). What are musical identities, and why are they important? In R. A. MacDonald, D. J. Hargreaves, \& D. Miell (Eds.), Handbook of Musical Identities (pp. 1-20). Oxford University Press.

Hargreaves, D. J., Purves, R. M., Welch, G. F., \& Marshall, N. A. (2007). Developing identities and attitudes in musicians and classroom music teachers. British Journal of Educational Psychology, 77(3), 665-682. doi:10.1348/000709906X154676

Hargreaves, E. (2015). Pedagogy, fear and learning. In D. Scott \& E. Hargreaves (Eds.), The SAGE Handbook of Learning (pp. 310-320). London: SAGE.

Hargreaves, E., \& Preece, S. (2014). The value of the personal in teachers' professional learning: a case study. Professional Development in Education, 40(1), 130-146. doi:10.1080/19415257.2013.770412

Healy, M. (2000). East meets West: Transformational learning and Buddhist meditation. In T. J. Sork, V.-L. Chapman, \& R. St. Clair (Eds.), Proceedings of the 41st Annual Adult Education Research Conference (pp. 576-6). Retrieved from https://files.eric.ed.gov/fulltext/ED452417.pdf

Heise, D. R. (1987). Affect control theory: Concepts and model. The Journal of Mathematical Sociology, 13(1-2), 1-33. https://doi.org/10.1080/0022250X.1987.9990025 
Hess, J. (2019). Singing our own song: Navigating identity politics through activism in music. Research Studies in Music Education, 41, 61-80. doi:10.1177/1321103X18773094

Higgins, E. T. (1987). Self-discrepancy: A theory relating self and affect. Psychological Review, 94(3), 319-340. doi:10.1037/0033-295X.94.3.319

Hirsch, G. (1993). Biography and teacher identity: a typological analysis of life-history data. International Journal of Qualitative Studies in Education, 6(1), 67-83. doi:10.1080/0951839930060106

Illeris, K. (2014). Transformative Learning and Identity (1st edition). London; New York: Routledge.

Illeris, K. (2015). Transformative learning. In The SAGE Handbook of Learning. [Chapter 31] (pp. 331-341). Retrieved from https://uk.sagepub.com/engb/eur/the-sage-handbook-of-learning/book242764

Kagan, D. M. (1992). Professional Growth Among Preservice and Beginning Teachers. Review of Educational Research, 62(2), 129-169. doi:10.3102/00346543062002129

Kemper, T. D. (1991). Predicting emotions from social relations. Social Psychology Quarterly, 54(4), 330-342. doi:10.2307/2786845

Kiecolt, K. J. (1994). Stress and the Decision to Change Oneself: A Theoretical Model. Social Psychology Quarterly, 57(1), 49-63. doi:10.2307/2786974

Klassen, R. M., Perry, N. E., \& Frenzel, A. C. (2012). Teachers' relatedness with students: An underemphasized component of teachers' basic psychological needs. Journal of Educational Psychology, 104(1), 150-165. doi:10.1037/a0026253 
Knowles, M. S. (1973). The adult learner : a neglected species. Retrieved from https://trove.nla.gov.au/version/26278487

Lamont, A. (2011). The beat goes on: music education, identity and lifelong learning. Music Education Research, 13(4), 369-388. doi:10.1080/14613808.2011.638505

Laros, A., Fuhr, T., \& Taylor, E. W. (2017). Transformative Learning Meets Bildung. Retrieved from https://www.sensepublishers.com/media/3021-transformativelearning-meets-bildung.pdf

Lum, C.-H. (2008). Home Musical Environment of Children in Singapore: On Globalization, Technology, and Media. Journal of Research in Music Education, 56(2), 101-117. doi:10.1177/0022429408317517

Markus, H., \& Nurius, P. (1986). Possible selves. American Psychologist, 41(9), 954969.

Maslow, A. (1962). Toward a psychology of being. NJ, US: Princeton, NJ: Princeton University Press.

McClellan, E. (2017). A social-cognitive theoretical framework for examining music teacher identity. Action, Criticism, and Theory for Music Education, 16(2), 65101. doi:10.22176/act16.2.65

McLean, K. C., \& Pratt, M. W. (2006). Life's little (and big) lessons: Identity statuses and meaning-making in the turning point narratives of emerging adults. Developmental Psychology, 42(4), 714-722. doi:10.1037/0012-1649.42.4.714

Merton, R. K., \& Merton, R. K. (1968). Continuities in the Theory of Reference Groups and Social Structure. New York, NY: Simon and Schuster. 
Mezirow, J. (1997). Transformative learning: Theory to practice. New directions for adult and continuing education, 1997(74), 5-12.

Mezirow, J. (1981). A Critical Theory of Adult Learning and Education. Adult Education, 32(1), 3-24. doi:10.1177/074171368103200101

Olsen, B. (2008). Introducing Teacher Identity and This Volume. Teacher Education Quarterly, 35(3), 3-6.

O’Neill, S. A. (2017). Young People's Musical Lives. In R. A. MacDonald, D. J. Hargreaves, \& D. Miell (Eds.), Handbook of Musical Identities (pp. 79-104). Oxford, UK: Oxford University Press.

oTranscribe [Online Software] (n.d.). Retrieved from https://otranscribe.com/

Palmer, P. J. (1997). The Heart of a Teacher Identity and Integrity in Teaching. Change: The Magazine of Higher Learning, 29(6), 14-21. doi:10.1080/00091389709602343

Pellegrino, K. (2009). Connections Between Performer and Teacher Identities in Music Teachers: Setting an Agenda for Research. Journal of Music Teacher Education, 19(1), 39-55. doi:10.1177/1057083709343908

Pellegrino, K. (2011). Exploring the Benefits of Music-Making as Professional Development for Music Teachers. Arts Education Policy Review, 112(2), 79-88. doi:10.1080/10632913.2011.546694

Pellegrino, K. (2015). Becoming music-making music teachers: Connecting music making, identity, wellbeing, and teaching for four student teachers. Research Studies in Music Education, 37(2), 175-194. doi:10.1177/1321103X15589336 
Pitts, S. (2005). Valuing Musical Participation: Case Studies of Music Identity and Belonging (1st ed). Aldershot, Hants, England; Burlington, VT: Routledge.

Pitts, S. (2012). Chances and Choices: Exploring the Impact of Music Education (1st ed). New York, NY: Oxford University Press.

Pope, M., \& Denicolo, P. (1993). The art and science of constructivist research in teacher thinking. Teaching and Teacher Education, 9(5-6), 529-544.

Priestley, M., Biesta, G., \& Robinson, S. (2015). Teacher Agency: An Ecological Approach. Bloomsbury Publishing.

Qi, N., \& Veblen, K. K. (2016). Transformative learning through music: Case studies from Brazil. Action, Criticism, and Theory for Music Education, 15(2), 101-125.

QSR International Pty Ltd. (2015). NVivo qualitative data analysis software (Version 11). Retrieved from https://www.qsinternational.com/

Regelski, T. A. (1998). The Aristotelian Bases of Praxis for Music and Music Education as Praxis. Philosophy of Music Education Review, 6(1), 22-59.

Regelski, T. A. (2007). 'Music Teacher' - meaning and practice, identity and position. Action, Criticism, and Theory for Music Education, 6(2), 1-35.

Regelski, T. A. (2012a). The Good Life of Teaching or the Life of Good Teaching? Action, Criticism, and Theory for Music Education, 11(2), 42-78.

Regelski, T. A. (2012b). Musicianism and the Ethics of School Music. Action, Criticism, and Theory for Music Education, 11(1), 7-42.

Riessman, C. K. (1993). Narrative Analysis: Qualitative Research Methods Series 30. London, England: SAGE Publications. 
Roberts, B. A. (2004). Who's in the mirror? Issues surrounding the identity construction of music educators. Action, Criticism, and Theory for Music Education, 3(2), 142.

Rodgers, C. R., \& Scott, K. H. (2008). The development of the personal self and professional identity in learning to teach. In J. Sikula (Ed.), Handbook of research on teacher education (pp. 732-755). New York, NY: Palgrave Macmillan.

Sachs, J. (2003). The activist teaching profession. Philadelphia, PA: Open University Press.

Sachs, J. (2011). Skilling or Emancipating? Metaphors for Continuing Teacher Professional Development. In N. Mockler \& J. Sachs (Eds.), Rethinking Educational Practice Through Reflexive Inquiry: Essays in Honour of Susan Groundwater-Smith (pp. 153-167). doi:10.1007/978-94-007-0805-1_11

Saldana, J. (2013). The Coding Manual for Qualitative Researchers. Los Angeles:

\section{SAGE.}

Schnare, B., MacIntyre, P., \& Doucette, J. (2012). Possible selves as a source of motivation for musicians. Psychology of Music, 40(1), 94-111. doi:10.1177/0305735610391348

Skaalvik, E. M., \& Skaalvik, S. (2014). Teacher Self-Efficacy and Perceived Autonomy: Relations with Teacher Engagement, Job Satisfaction, and Emotional Exhaustion. Psychological Reports, 114(1), 68-77. doi:10.2466/14.02.PR0.114k14w0

Skerrett, A. (2008). Biography, Identity, and Inquiry: The making of teacher, teacher educator, and researcher. Studying Teacher Education, 4(2), 143-156. doi:10.1080/17425960802433629 
Smith, J. A., Flowers, P., \& Larkin, M. (2009). Interpretative Phenomenological Analysis. Singapore: SAGE.

Spilt, J. L., Koomen, H. M. Y., \& Thijs, J. T. (2011). Teacher Wellbeing: The Importance of Teacher-Student Relationships. Educational Psychology Review, 23(4), 457477. doi:10.1007/s10648-011-9170-y

Stets, J. E., \& Burke, P. J. (2003). A sociological apporach to self and identity. In M. R. Leary \& J. P. Tangney, Handbook of Self and Identity (pp. 128-142). New York: The Guilford Press.

Taylor, A. (2011). Continuity, change and mature musical identity construction: Using 'Rivers of Musical Experience' to trace the musical lives of six mature-age keyboard players. British Journal of Music Education, 28(2), 195-212. doi:10.1017/S0265051711000076

Taylor, A. (2015). Using Interpretative Phenomenological Analysis in a Mixed Methods Research Design to Explore Music in the Lives of Mature Age Amateur Keyboard Players. Music Education Research, 17(4), 437-452.

doi:10.1080/14613808.2014.906397

Taylor, E. W. (1998). The Theory and Practice of Transformative Learning: A Critical Review. Information Series No. 374. Retrieved from https://eric.ed.gov/?id=ED423422

Taylor, E. W. (2017). Transformative learning theory. In A. Laros, T. Fuhr, \& E. W. Taylor (Eds.), Transformative Learning Meets Bildung: An International Exchange. [Chapter 2] (pp. 17-29). Retrieved from //www.springer.com/la/book/9789463007979 
Taylor, E. W., \& Cranton, P. (2013). A theory in progress?: Issues in transformative learning theory. European Journal for Research on the Education and Learning of Adults, 4(1), 35-47. doi:10.3384/rela.2000-7426.rela5000

Tisdell, E. J. (2003). Exploring Spirituality and Culture in Adult and Higher Education. San Francisco, CA: Jossey-Bass.

Tschannen-Moran, M., Hoy, A. W., \& Hoy, W. K. (1998). Teacher Efficacy: Its Meaning and Measure. Review of Educational Research, 68(2), 202-248. doi:10.3102/00346543068002202

Wagoner, C. L. (2011). Defining and Measuring Music Teacher Identity: A Study of SelfEfficacy and Commitment among Music Teachers. Greensboro: The University of North Carolina at Greensboro.

Wenger, E. (2009). A social theory of learning. In K. Illeris (Ed.), Contemporary theories of learning: learning theorists-in their own words (pp. 209-218). New York: Routledge.

Yost, D. S. (2006). Reflection and Self-Efficacy: Enhancing the Retention of Qualified Teachers from a Teacher Education Perspective. Teacher Education Quarterly, $33(4), 59-76$. 